\title{
Nauplius
}

The Journal of The

Brazilian Crustacean Society

This article is part of the tribute offered

by the Brazilian Crustacean Society

in memoriam of Michael Türkay for his

e-ISSN 2358-2936

www.scielo.br/nau

www.crustacea.org.br

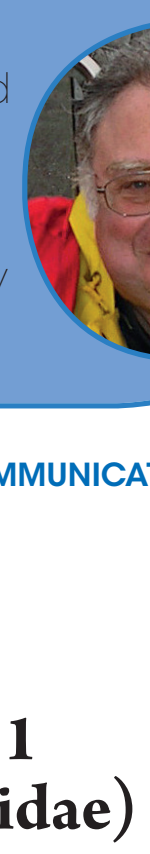

\section{On the extant type material of Cardisoma hirtipes Dana, 1851, and Cardisoma obesum Dana, 1851 (Crustacea: Brachyura: Gecarcinidae)}

\author{
Peter K. L. $\mathrm{Ng}^{1}$ \\ ${ }^{1}$ Lee Kong Chian Natural History Museum, National University of Singapore, Kent \\ Ridge, Singapore 119260, Republic of Singapore. \\ ZOOBANK http://zoobank.org/urn:lsid:zoobank.org:pub:3BCAD6EA-E72F-4889- \\ 8941-1ECD60E74E51
}

\begin{abstract}
Two boxes in the U.S. National Museum of Natural History, Smithsonian Institution, were found to contain the dried type material of the land crabs Cardisoma hirtipes Dana, 1851, and Cardisoma obesum Dana, 1851 (Gecarcinidae). The types of the common Pacific land crab, C. hirtipes were believed to have been lost and a neotype had been designated in earlier revisions. Cardisoma obesum Dana, 1851 is currently regarded as a junior subjective synonym of Cardisoma carnifex (Herbst, 1796).
\end{abstract}

\section{Key WORDS}

Land crab, type specimens, Dana material, Cardisoma, taxonomy.

CORRESPONDING AUTHOR Peter K. L. Ng

peterng@nus.edu.sg

SUBMITTED 13 February 2017

ACCEPTED 12 April 2017

PUBLISHED 22 June 2017

Guest Editor

Célio Magalhães

DOI 10.1590/2358-2936e2017019 


\section{TAXONOMY}

\section{Family Gecarcinidae MacLeay, 1838}

\section{Genus Discoplax A. Milne-Edwards, 1867}

\section{Discoplax hirtipes (Dana, 1851)}

(Figs. 1-3)

Cardisoma hirtipes Dana, 1851: 253 (for complete synonymy, see $\mathrm{Ng}$ and Shih, 2014: 112).

Type material. Lectotype male $(58.2 \times 47.4 \mathrm{~mm})$ (USNM 2356), "Viti” (= Fiji), ca. $17^{\circ} 48^{\prime} \mathrm{S} 178^{\circ} 00^{\prime} \mathrm{E}$, coll. U.S. Exploring Expedition.

Remarks. Cardisoma hirtipes was described by Dana (1851: 253) from "Viti" (= Fiji), who listed only one specimen (sex not specified) measuring $28 \times 22.5$ lines (see also Dana, 1852: 376). Dana (1852: 377) redescribed the species, noting that the specimen was a male from the "Feejee Islands". This was apparently the same specimen figured by him later (Dana, 1855: pl. 24, fig. 2). The line was an English unit of measure that has been variously equivalent to $1 / 10,1 / 12,1 / 16$ or $1 / 40$ of an inch $(=25.4 \mathrm{~mm})$. In the older literature, Englishspeaking biologists usually equated a line with $1 / 12$ of an inch (or $2.1 \mathrm{~mm}$ ). That would put the dimensions of Dana's male specimen at $58.8 \times 47.3 \mathrm{~mm}$. Evans (1967) had listed a type specimen of the Pacific land crab C. hirtipes (Gecarcinidae) in the Natural History Museum, London (see also Türkay, 1974). Ng and Clark (2014) examined the specimen and argued that this was actually not a type, belonging to another species, Cardisoma carnifex (Herbst, 1796), instead. They commented that since there were no extant types of the species, the neotype male specimen from Fiji designated by Ng and Davie (2012) therefore remained the valid type of $C$. hirtipes.

The present specimen (USNM 2356) is a male $58.2 \times 47.4 \mathrm{~mm}$ and agrees well with the size given by Dana (1851): $58.8 \times 47.3 \mathrm{~mm}$. There is no doubt this is the specimen examined and figured by Dana (1851; 1852; 1855). Although Dana (1851; 1852;

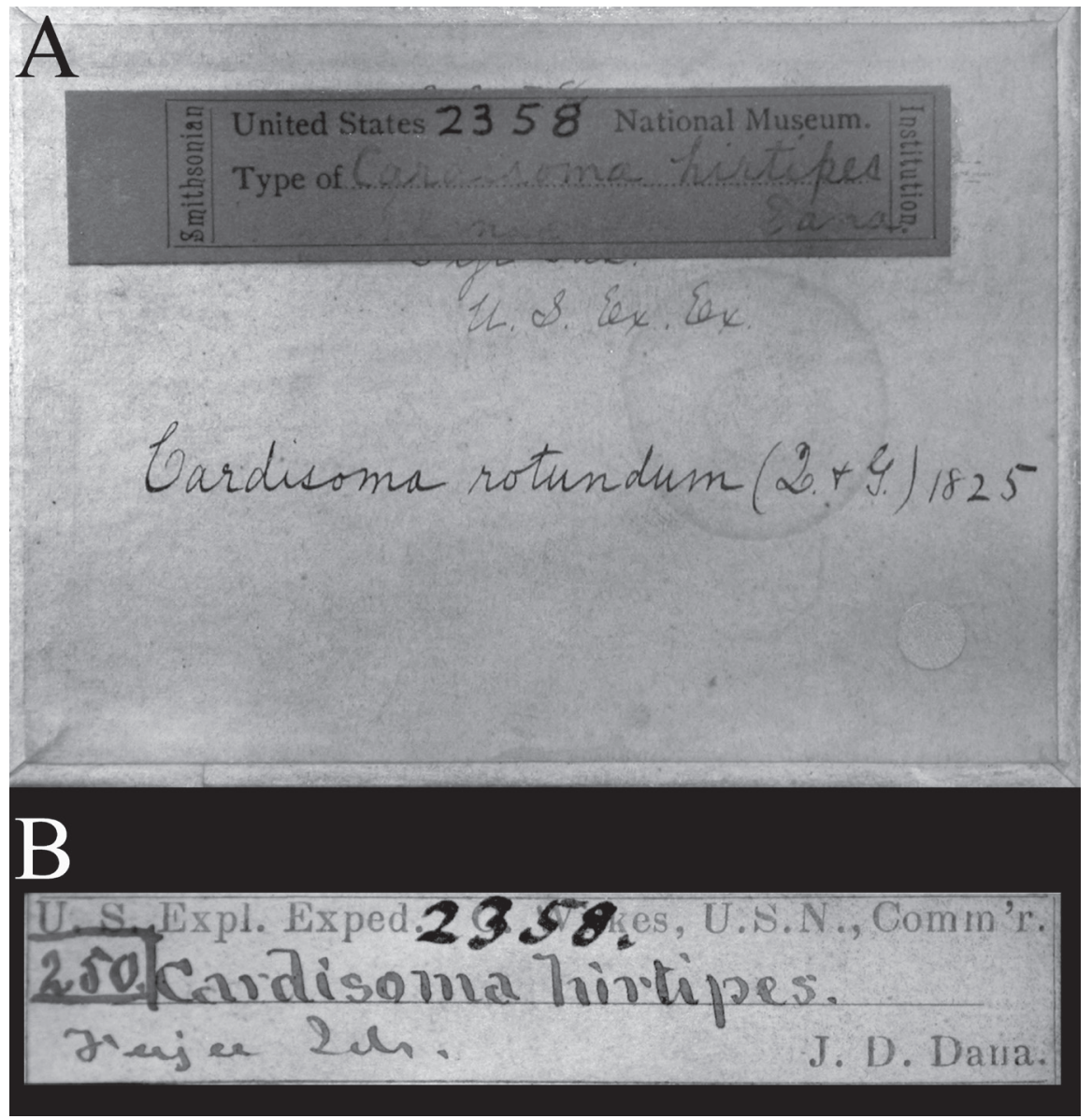

Figure 1. Labels associated with the lectotype of Cardisoma hirtipes Dana, 1851. A, box cover; B, label inside box. 
1855) mentioned and figured only this one specimen, he did not state it was the holotype or make it clear he only had one specimen (see Ng and Clark, 2014). As such, it is preferable to designate USNM 2356 as the lectotype of $C$. hirtipes.

The present lectotype is interesting as the left male first gonopod (G1) had been detached (Figs. 2D, 3I). The G1 was subsequently rehydrated and was shelved in the wet collections of the USNM (Fig. 3J-M). Who did this is not known as neither the box with the dried body or the bottle with the G1 had any labels to this effect.

Interestingly, Türkay (1974: 233) listed among his material examined for $D$. hirtipes (as a Cardisoma Latreille in Latreille, Le Peletier, Serville \& Guérin, 1828) as follows: "Südsee, Viti ( $1 \mathrm{Go} / 1$ des Holotypus von Cardisoma hirtipes DANA 1851)". He did not indicate where the specimen was from and which museum it was kept in, and was not discussed anywhere

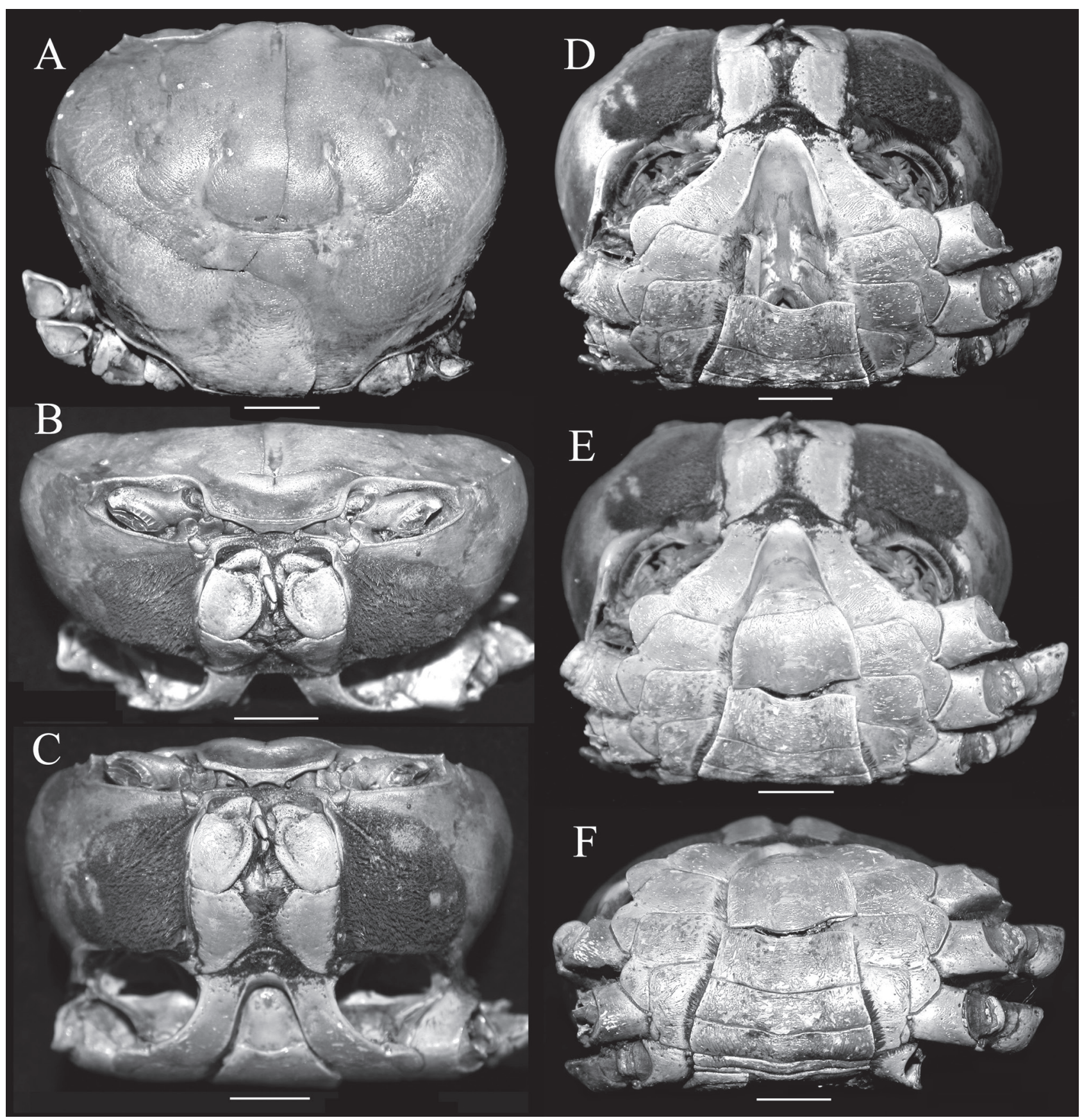

Figure 2. Cardisoma hirtipes Dana, 1851, lectotype male (58.2 ×47.4 mm) (USNM 2356). A, dorsal view of carapace; B, C, frontal view of cephalothorax; D-F, ventral view of of cephalothorax showing thoracic sternum and abdomen. Scale bars $=10.0 \mathrm{~mm}$. 
else in his paper. Ng and Clark (2014:596) was advised by the late Michael Türkay that he had actually not examined the holotype of the species and the type he had referred to was the specimen recorded by Evans (1967). Could the detached G1 in USNM be the one he had actually examined instead and then inadvertently forgot in the ensuing years?

The discovery of the present lectotype means that the neotype selected by Ng and Davie (2012) is now no longer a type specimen. The species is currently classified in the genus Discoplax A. Milne-Edwards, 1867 (see Ng and Guinot, 2001; Ng and Shih, 2014).

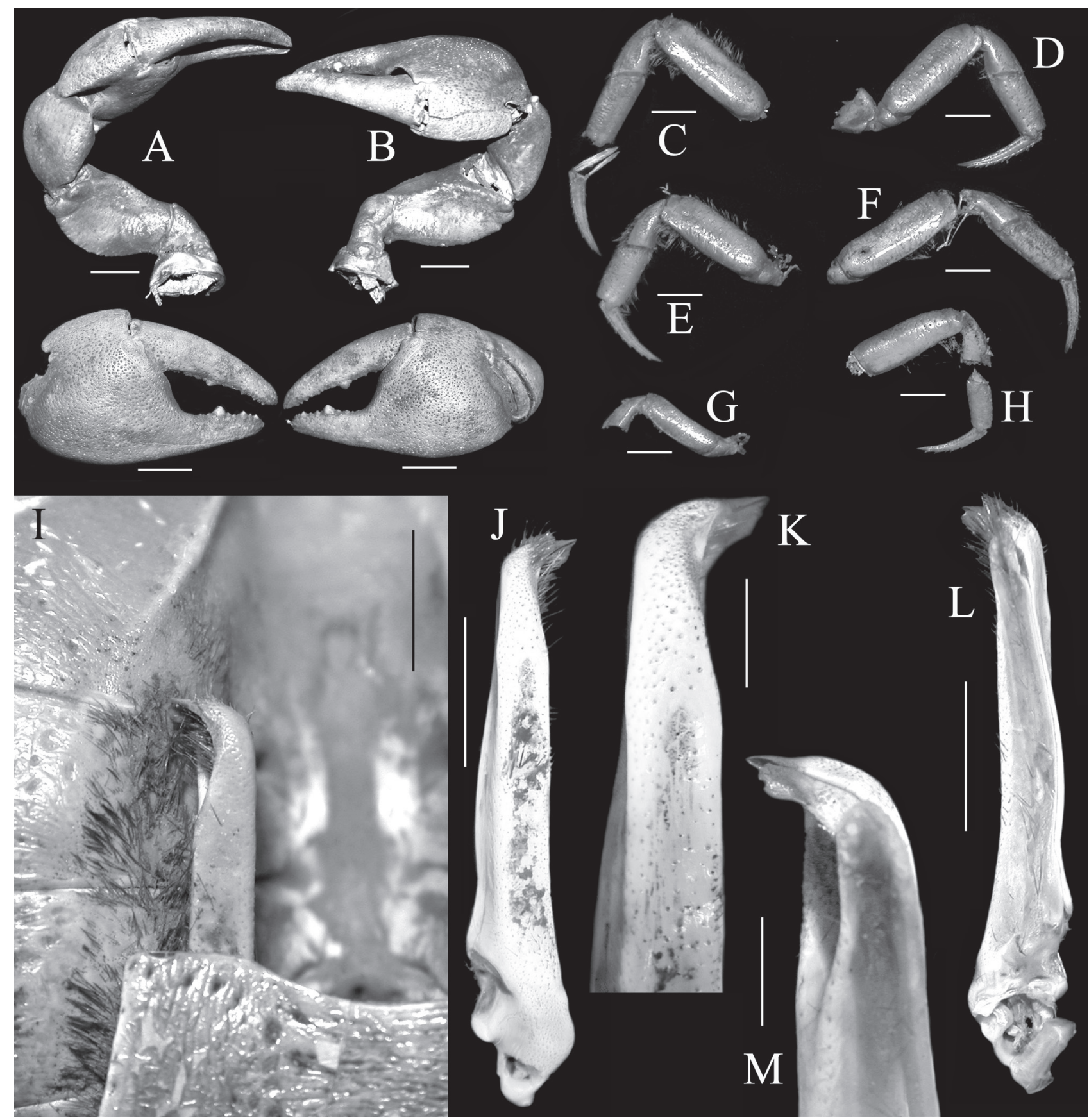

Figure 3. Cardisoma hirtipes Dana, 1851, lectotype male $(58.2 \times 47.4 \mathrm{~mm})$ (USNM 2356). A, dorsal view of left cheliped; B, dorsal view of right cheliped; $C$, outer view of right chela; $D$, outer view of left chela; $C$, left first ambulatory leg; $D$, right first ambulatory leg; E, left second ambulatory leg; F, right second ambulatory leg; G, left fourth ambulatory leg; H, right third ambulatory leg; I, sternoabdominal cavity with intact right G1; J, ventral view of left G1; K, distal half of left G1, ventral view (denuded); L, dorsal view of left G1; M, distal half of left G1, dorsal view (denuded). Scale bars: A-H = $10.0 \mathrm{~mm}$; J, L = 5.0 mm; K, M = $2.0 \mathrm{~mm}$. 


\section{Cardisoma carnifex (Herbst, 1796)}

(Figs. 4, 5)

Cancer carnifex Herbst, 1796: 163, pl. 41, fig. 1 (for complete synonymy, see Türkay, 1974: 224).

Cardisoma obesum Dana, 1851: 252.

Type material. 1 carapace $(90.6 \times 70.0 \mathrm{~mm})(\mathrm{USNM}$ 2356), Peacock Island, Tuamotu, $14^{\circ} 30^{\prime} \mathrm{S} 146^{\circ} 18^{\prime} \mathrm{W}$, coll. U.S. Exploring Expedition.

Remarks. Cardisoma obesum was described by Dana (1851: 252-253) from "Paumotu" (= Tuamotu) in French Polynesia, and he listed one specimen (sex not specified) measuring 3.67 by 3 inches $(93.2 \times 76.2$ $\mathrm{mm})$. Dana (1852:376) redescribed the species and figured the carapace, noting that it was from Peacock Island in the Paumotu Archipelago, and that the "... only specimen of this species saved from among the many collected, is a carapax." The front of the carapace was figured in Dana (1855: pl.24, fig. 1). Cardisoma obesum is currently regarded as a junior subjective synonym of C. carnifex (see Türkay, 1974). The whereabouts of the type of C. obesum, was to date not known.

The present specimen (USNM 2356) measures $90.6 \times 70.0 \mathrm{~mm}$ and the measurements are slightly smaller from that given by Dana (1851) but this can

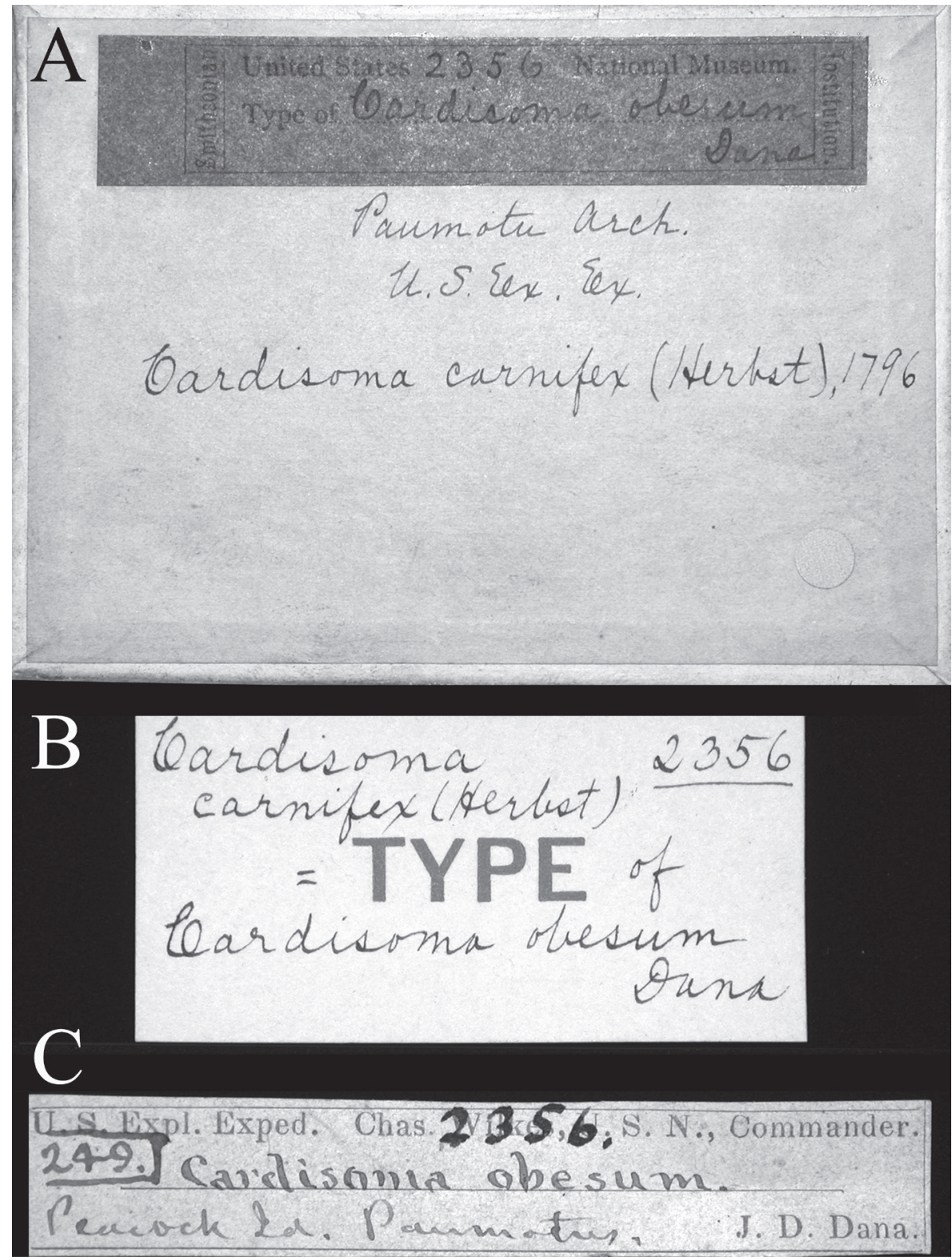

Figure 4. Labels associated with the lectotype of Cardisoma obesum Dana, 1851. A, box cover; B, C, labels inside box. 


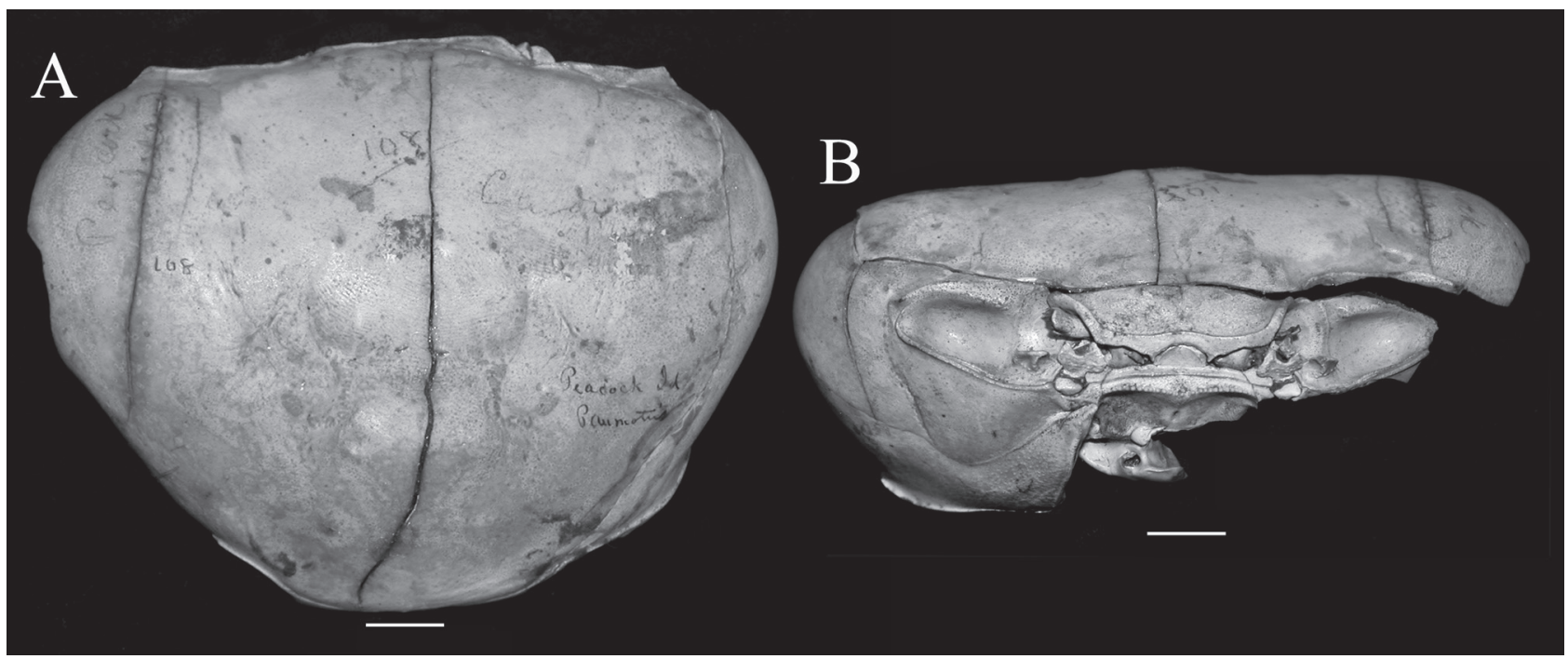

Figure 5. Cardisoma obesum Dana, 1851, lectotype male ( $90.6 \times 70.0 \mathrm{~mm})$ (USNM 2356). A, dorsal view of carapace; B, frontal view of cephalothorax. Scale bars $=10.0 \mathrm{~mm}$.

easily be explained by the fact that all that is left of the specimen is the carapace and the left side is broken and in poor condition. As thus, there is doubt this is in fact the holotype specimen of C. obesum.

\section{ACKNOWLEDGEMENTS}

The author is grateful to Rafael Lemaitre and Karen Reed (USNM) for helping him find the dried specimens in question. The visit to USNM was facilitated by a travel grant from the National University of Singapore. This note is dedicated to an old friend, Michael Türkay, and the author of so many important papers on Brachyura, including especially the Gecarcinidae, which he always loved.

\section{References}

Anonymous. 1851. Conspectus Crustaceorum, \&c.; Crustacea of the Exploring Expedition; by James D. Dana. - Crustacea Grapsoidea, (Proceedings of the Academy of Natural Sciences of Philadelphia, 1851: 247). In: Scientific Intelligence. II Botany and Zoology. American Journal of Science and Arts, ser. 2, 12 (36) [November]: 439.

Anonymous. 1852. Books added to the Library up to December 31 st [1851]. Proceedings of the Boston Society of Natural History, 4: $171-174$.

Dana, J.D. 1851. Conspectus Crustaceorum quae in Orbis Terrarum circumnavigatione, Carolo Wilkes e Classe Reipublicae Foederatae Duce. Crustacea Grapsoidea, (Cyclometopa, Edwardsii). Proceedings of the Academy of Natural Sciences of Philadelphia, 5(10): 247-254. [Published before 30 November 1851 (Anonymous, 1851: 439), and 31 December 1851 (Anonymous, 1852: 173); also issued as a separate with the same title and pagination 1-8]
Dana, J.D. 1852. Crustacea. Part I. In: United States Exploring Expedition, During the Years 1838, 1839, 1840, 1841, 1842, Under the Command of Charles Wilkes, U.S.N., 13(1): i-viii, 1-685. Philadelphia, C. Sherman.

Dana, J.D. 1855. Crustacea: Atlas. In: United States Exploring Expedition during the years 1838, 1839, 1840, 1841, 1842, under the Command of Charles Wilkes, U.S.N., 14: 1-27, pls. 1-96.

Evans, A.C. 1967. Syntypes of Decapoda described by William Stimpson and James Dana in the collections of the British Museum (Natural History). Journal of Natural History, 1: 399-411.

Herbst, J.F.W. 1782-1804. Versuch einer Naturgeschichte der Krabben und Krebse nebst einer systematischen Beschreibung ihrer verschieden Arten. Gottlieb August Lange, Berlin \& Stralsund. Volumes 1-3: 1-274 + 1-226+1-66 + 1-46, 1-54 +1-49, Pls. 1-62. [Vol. 1, Part 1 (Pp. 1-86, Pl. 1): 1782; Vol. 1, Parts 2-5 (Pp. 87-182, Pls. 2-9): 1783; Vol. 1, Part 6 (Pp. 183-206, Pls. 10-13): 1785; Vol. 1, Part 7 (Pp. 207-238, Pls. 14-17): 1788; Vol. 1, Part 8 (Pp. 239-274, Pls. 18-21): 1790; Vol. 2, Part 1 (Pp. 1-48, Pls. 22-25): 1791; Vol. 2, Part 2 (Pp. 49-78, Pls. 26-29): 1792; Vol. 2, Part 3 (Pp. 79-98, Pls. 30-33): 1793; Vol. 2, Part 4 (Pp. 99-146, Pls. 34-36): 1793; Vol. 2, Part 5 (Pp. 147-162, Pls. 37-40): 1794; Vol. 2, Parts 6-end (Pp. 163-226, Pls. 41-46): 1796; Vol. 3, Part 1 (1-66, Pls. 47-50): 1799; Vol. 3, Part 2 (Pp. 1-46, Pls. 51-54): 1801; Vol. 3, Part 3 (Pp. 1-54, Pls. 55-58): 1803; Vol. 3, Part 4 (Pp. 1-49, Pls. 59-62): 1804.] [For dates of publication, see Rathbun, 1897: 157; Sherborn, 1902: xxix]

MacLeay, W.S. 1838. On the Brachyurous Decapod Crustacea. Brought from the Cape by Dr. Smith. In Smith, A., Illustrations of the Zoology of South Africa; consisting chiefly of figures and descriptions of the objects of natural history collected during an expedition into the interior of South Africa, in the years 1834, 1835, and 1836; fitted out by 'The Cape of Good Hope Association for Exploring Central Africa': together with a summary of African Zoology, and an inquiry into the geographical ranges of species in that quarter of the globe, 
published under the Authority of the Lords Commissioners of Her Majesty's Treasury, Invertebratae. IV [1849]. pp. 53-71, pls. 2, 3. London, Smith, Elder \& Co.

Milne-Edwards, A. 1867. Description de quelques espèces nouvelles de Crustacés Brachyoures. Annales de la Société Entomogique de France, (4)7: 263-288.

Ng, P.K.L. and Clark, P.F. 2014. The type of the land crab Cardisoma hirtipes Dana, 1851 (Crustacea: Brachyura: Gecarcinidae). Zootaxa, 3860: 596-599.

Ng, P.K.L. and Davie, P.J.F. 2012. The Blue Crab of Christmas Island, Discoplax celeste, new species (Crustacea: Decapoda: Brachyura: Gecarcinidae). Raffles Bulletin of Zoology, 60: 89-100.

Ng, P.K.L. and Guinot, D. 2001. On the land crabs of the genus Discoplax A. Milne-Edwards, 1867 (Crustacea: Decapoda: Brachyura: Gecarcinidae), with description of a new cavernicolous species from the Philippines. Raffles Bulletin of Zoology, 49: 311-338.
Ng, P.K.L. and Shih, H.-T. 2014. The systematics of the land crabs of the Discoplax hirtipes (Dana, 1851) species-group (Crustacea: Decapoda: Brachyura: Gecarcinidae), with description of a new species from the eastern Indian Ocean. In: H.H. Tan, M. Orchard, P.J.F. Davie and P.K.L. Ng (eds), Christmas Island and Cocos (Keeling) Islands: Biodiversity and Management Challenges. Raffles Bulletin of Zoology, Supplement 30: 109-135.

Rathbun, M.J. 1897. A revision of the nomenclature of the Brachyura. Proceedings of the Biological Society of Washington, 11: 153-167.

Sherborn, C.D. 1902. Index animalium sive index nominum quae ab A.D. MDCCLVIII generibus et speciebus animalium imposita sunt societatibus eruditorum adiuvantibus. Sectio prima a kalendis Ianuariis, MDCCLVIII usque ad finem Decembris, MDCCC. Cambridge, Cambridge University Press.

Türkay, M. 1974. Die Gecarcinidae Asiens und Ozeaniens (Crustacea: Decapoda). Senckenbergiana biologica, 55: 223-259. 